\title{
Seorang Perempuan Perokok Tembakau dan Mariyuana dengan Pneumotoraks Spontan Primer Akibat Blep Multipel yang Pecah
}

\author{
Yenny Kusmatuti, Isnin Anang Marhana \\ Departemen Pulmonologi dan Ilmu Kedokteran Respirasi, Fakultas Kedokteran Universitas Airlangga/RSUD Dr Soetomo
}

\begin{abstract}
Background. Primary spontaneous pneumothorax (PSP) can be caused by a ruptured blep emfisematus subpleural. People who smoke tobacco and marijuana simultaneously arise PSP will be more risky than just smoking tobacco. Pneumothorax in cannabis smokers may occur due to coughing at the time was holding their breath, when they were smoking marijuana. Case. We report the case of 33-year-old woman with recurrent shortness of breath as a result of primary spontaneous pneumothorax in the right hemithorax. The patient's tobacco and marijuana smokers. Patients had undergone previous pleurodesis. Chest X-ray picture of the lines conveniently indicates lung collapse and air-fluid level in the right hemithorax. Thoracoscopic showed a large bronchopleural fistula. During thoracotomy found one bronkopeural fistula, three large blep, and more than 15 small blep. Then do the suturing of fistula and blep. Patients recover in a short time and in good condition during treatment. Conclusion. Tobacco and marijuana smoking is a risk factor that is synergistic to the occurrence of primary spontaneous pneumothorax. These patients consume both are irregular but have resulted in multiple blep that can rupture and cause a pneumothorax.
\end{abstract}

Key words: Marijuana, Tobacco, Pneumotraks

\section{PENDAHULUAN}

Pneumotoraks adalah suatu kondisi di mana terdapat udara di dalam rongga pleura. Pneumotoraks dapat diklasifikasikan berdasarkan proses terjadinya, lokasi, dan derajat kolaps paru. Penumotoraks lebih sering terjadi pada penderita dewasa muda. Lakilaki lebih sering daripada perempuan. Penumotoraks sering dijumpai pada musim penyakit batuk. ${ }^{1}$

Insiden pneumotoraks spontan primer di Amerika Serikat adalah 7,4/100.000 per tahun pada lakilaki dan 1,2/100.000 per tahun pada perempuan, sedangkan kasus pneumotoraks spontan sekunder adalah 6,3/100.000 per tahun pada laki-laki dan 2,0/100.000 per tahun pada perempuan. Di RSUD Dr. Soetomo didapatkan $55 \%$ kasus pneumotoraks yang terjadi akibat penyakit dasarnya seperti tuberkulosis paru aktif, tuberkulosis paru yang disertai fibrosis atau emfisema lokal, bronkitis kronik, dan PPOK. Kematian akibat pneumotoraks lebih kurang $12 \% .^{1,2}$

Blep pleura adalah terdapatnya sejumlah kecil udara di subpleura pada lapisan pleura viseral. Lesi tersebut akan memberikan gejala bila telah terjadi komplikasi pneumotoraks spontan. Blep terjadi akibat ruptur kecil pada alveoli yang robek sampai ke interstisial dan akan membentuk kumpulan udara dalam jumlah sedikit di daerah subpleura. Lesi yang menimbulkan pneumotoraks spontan terutama berlokasi di daerah apeks lobus superior paru atau apeks segmen superior. Sebagian besar pasien dengan blep tidak memiliki penyakit tertentu yang mendasari timbulnya blep. ${ }^{3}$

Berikut ini akan dilaporkan sebuah kasus yaitu seorang perempuan perokok tembakau dan mariyuana dengan pneumotoraks spontan primer akibat blep multipel yang pecah 


\section{KASUS}

Seorang perempuan, Ny I, berusia 33 tahun, berdomisili di jalan Lebak Jaya Utara dan bekerja pada Hotel sebagai Supervisor Resepsionis. Masuk rumah sakit (MRS) dengan keluhan sesak napas. Penderita merasakan sesak napas sejak delapan hari yang lalu. Sesak napas mendadak dan sesak terasa semakin berat. Sesak napas tidak berkurang dengan istirahat atau perubahan posisi. Batuk jarang dan tidak ada dahak. Keringat malam dan penurunan berat badan tidak didapatkan. Nyeri dada didapatkan. Buang air besar dan buang air kecil tidak terdapat kelainan. Penderita dirujuk dari rumah sakit swasta setelah dirawat selama delapan hari. Penderita telah dilakukan pemasangan drainase torakal yang disambungkan ke WSD. Setelah beberapa kali dilakukan foto evaluasi dan paru tetap mengembang, satu hari sebelum masuk rumah sakit (SMRS) dilakukan pleurodesis dengan povidon iodine, setelah dilakukan pleurodesis, keesokan harinya dilakukan foto toraks evaluasi dan paru terlihat kolaps kembali, dan penderita dirujuk ke RSUD Dr. Soetomo dalam kondisi masih terpasang drainase torakal.

Berdasarkan riwayat, penderita merokok (rokok tembakau) sejak 15 tahun yang lalu sekitar 2-3 pak perhari dan mulai berkurang sejak 1 tahun sebelum MRS menjadi kurang dari setengah pak perbulan. Sekitar 3 tahun yang lalu penderita juga merokok (digunakan secara bersama) dengan mariyuana, tetapi tidak rutin dan berlangsung selama enam bulan. Riwayat memakai shabu-shabu selama 2 tahun, tetapi tidak pernah memakai narkotika jenis lain. Penderita juga alkoholik. Riwayat seks bebas disangkal.

Berdasarkan Pemeriksaan fisik; Penderita datang dengan keadaan umum cukup, kesadaran kompos mentis dengan GCS 456 , tensi $110 / 80 \mathrm{mmHg}$, nadi $88 \mathrm{x} /$ menit, frekuensi napas $28 \mathrm{x} /$ menit, dan suhu aksiler $36,4 \mathrm{C}$. Kepala dan leher tidak didapatkan tanda-tanda anemis, ikterus, sianosis, serta tidak ada pembesaran kelenjar getah bening maupun peningkatan vena jugularis. Pada regio toraks, inspeksi tampak pergerakan dada asimetris dengan hemitoraks kanan tertinggal. Pada palpasi didapatkan fremitus raba hemitoraks kanan menurun. Pada perkusi didapatkan hipersonor pada hemitoraks kanan. Pada auskultasi tidak didapatkan suara vesikuler pada hemitoraks kanan. Tidak didapatkan suara wheezing dan ronki pada kedua hemitorak. Didapatkan egofoni pada hemitoraks kanan bawah. Pada pemeriksaan jantung, suara jantung (S1 dan S2) tunggal, tidak didapatkan murmur maupun gallop.

Berdasarkan pemeriksaan abdomen, hepar dan lien tidak teraba, tidak didapatkan massa intra abdomen maupun nyeri tekan. Bising usus dalam batas normal.

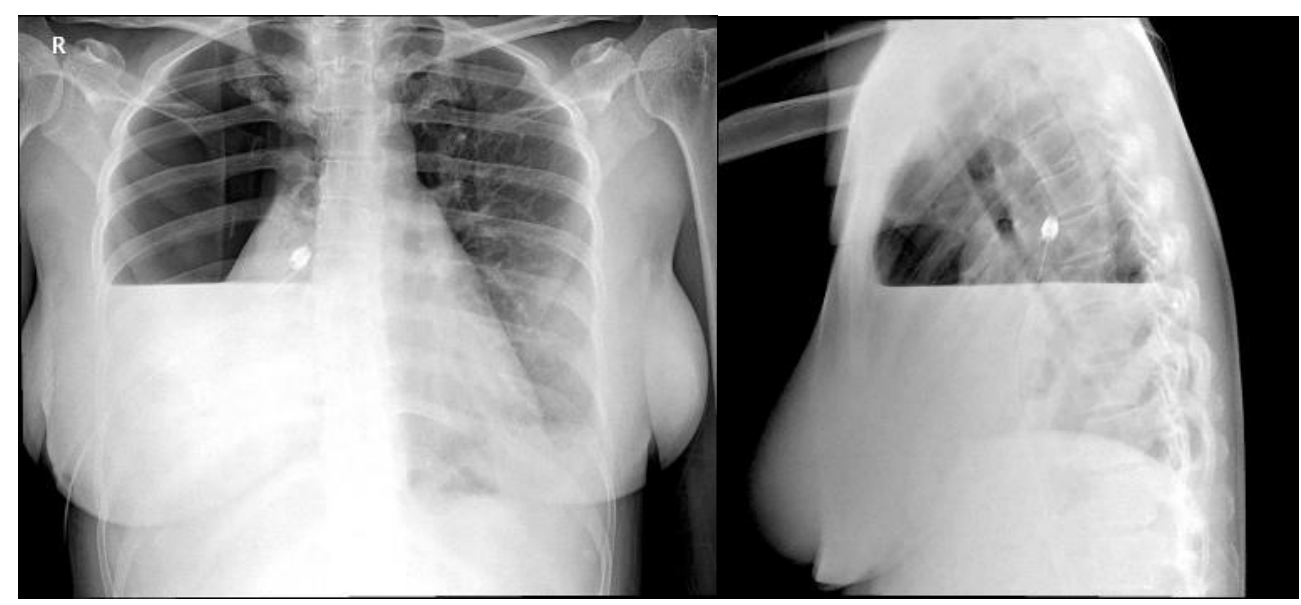

Gambar 1. Foto toraks.

\section{SEQUENCE OF EVENT}

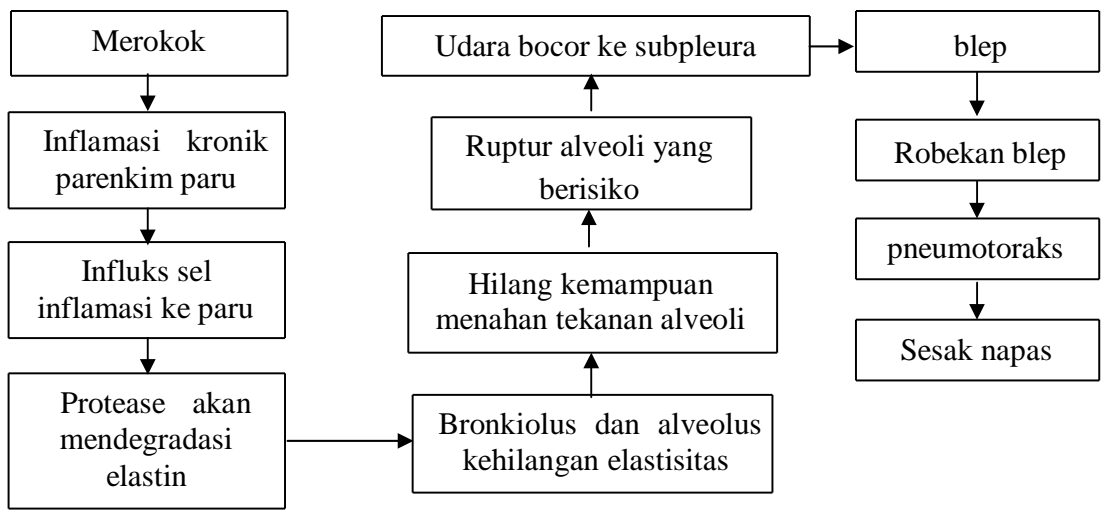


Pemeriksaan anggota gerak tidak ada edema, jari tabuh, serta tidak didapatkan pembesaran kelenjar getah bening di ketiak maupun lipatan paha. Berdasarkan pemeriksaan darah;Hb15,1 gr/dl, Leukosit 12.500 / ul, Granulosit 77,1\%, Trombosit245.000/ul, HCT 46,7 \%, Glukosa102mg/dl, SGOT23 u/l, SGPT20 u/l, Albumin 3,48mg/dl, BUN5mg/ $\mathrm{dl}$, kreatinin serum $0,67 \mathrm{mg} / \mathrm{dl}$, Natrium 137,4mmol, Kalium4,04 mmol, klorida 102,1 mmolBGA;pH7,37; $\mathrm{PCO}_{2} 38 \mathrm{mmHg} ; \mathrm{PO}_{2} 115 \mathrm{mmHg} ; \mathrm{HCO}_{3} 22,0 \mathrm{mmol} / \mathrm{B} ; \mathrm{BE}$ $-3,3 ; \mathrm{SO}_{2} 98 \%$

Berdasarkan pemeriksaan foto toraks (Gambar 1); didapatkan trakea teresan terdorong ke kiri Jantung: batas jantung kanan tertutup perselubungan, kesan terdorong ke kiri, Pulmo; lapang paru kanan tampak garis kolaps, air fluid level, dan bayangan chest tube. Lapangan paru kiri tak tampak infiltrat atau nodul, Sudut frenikokostalis kanan tertutup perselubungan, kiri anterior posterior tajam, Retrosternal space normal, retrocardial space tertutup perselubungan. Penderita didiagnosa sementara yaitu; sesak napas dan pneumotoraks spontan primer dekstra. Perkembangan penderita dibagi menjadi 3 tahap yaitu;

1. Tahap penegakan diagnosis pneumotoraks spontan primer;

Pasien MRS di rumah sakit swasta dengan keluhan sesak napas tiba-tiba kemudian di foto rontgen toraks dan dinyatakan pneumotoraks paru kanan, dilakukan pemasangan drainase torakal yang kemudian disambungkan dengan WSD. Pasien dilakukan evaluasi foto toraks sebanyak 4 kali dan didapatkan paru mengembang dengan baik, kemudian dilakukan pleurodesis dengan povidon iodine dan dilakukan foto toraks evaluasi dan didapatkan paru kembali kolaps dan timbul gambaran air fuid level pada gambaran foto toraks yang diduga merupakan cairan pleurodesis yang digunakan satu hari sebelumnya. Satu minggu MRS di rumah sakit swasta kemudian pasien dirujuk ke RSUD Dr. Soetomo untuk penegakan diagnosis penyebab rekurensi pneumotoraks.

Pasien tiba di IRD RSUD Dr. Soetomo dalam kondisi cukup baik dan masih terpasang drainase torakal. Pasien sesak napas dengan pernapasan $28 \mathrm{kali} /$ menit. Tidak dilakukan foto ulang pada pasien karena foto dari rumah sakit yang merujuk dilakukan pada hari yang sama. Pada foto rontgen terlihat adanya gambaran garis kolaps paru dan air fluid level pada paru kanan dengan posisi trakea, jantung dan mediastinum agak terdorong ke sebelah kiri. Pasien direcanakan untuk dilakukan torkoskopi di ruang tindakan paru pada jam kerja. Terapi yang diberikan pada pasien adalah pemberian oksigen 3 liter/menit, fisioterapi dada, dan pemasangan continuos suction.

Satu hari MRS pasien di konsultasikan ke kardiologi untuk penilaian Cardiac Risk Index (CRI) dengan jawaban: saat ini di bidang kardiologi kami dapatkan pasien dengan Cardiac Risk Index class I (risk of Major Adverse Cardiac Event 0,3\%). Pasien juga dikonsultasikan ke rehabilitasi medik dengan jawaban: kami temukan pasien dengan abnormalitas pernapasan karena pneumotoraks rekuren dekstra post pleurodesis. Dilakukan rawat bersama dan tindakan latihan pernapasan berupa deep breathing dan pursed-lip breating, breathing control dan relaksasi; AROM excersise, dan latihan mobilisasi duduk-berdiri. Pemeriksaan faal paru di dapatkan hasil: FVC $1160 \mathrm{~mL}$ (42\% predicted), $\mathrm{FEV}_{1} 1160 \mathrm{~mL}$ (48\% predicted), $\mathrm{FEV}_{1} /$ FVC $100 \%$. Kesimpulan: restriksi berat tanpa obstruksi. Dilakukan pemeriksaan analisa cairan pleura dengan hasil: jumlah sel pleura $4100 \mathrm{sel} / \mathrm{uL}$, mononuklear 75\%, polinuklear, $25 \%$, glukosa cairan pleura $94 \mathrm{mg} / \mathrm{dL}$, protein cairan pleura 4,10 g/dL, LDH cairan pleura $912 \mathrm{U} / \mathrm{L}$.

Dua hari MRS di RSUD Dr Soetomo dilakukan tindakan torakoskopi pada kavum pleura dengan hasil: pleura viseralis dan parietalis tidak tampak penebalan. Di rongga pleura tidak tampak fibrotic band. Tampak fistula bronkopleural pada pleura viseralis kanan. Kemudian dilakukan pemasangan chest tube no. 28

Pada pemeriksaan torakoskopi hanya terlihat satu fistula dengan ukuran yang cukup besar. Pasien kemudian direncanakan untuk dilakukan konsultasi dengan divisi bedah torak dan kardiovaksuler untuk penutupan fistula tersebut.

Tiga hari MRS dilakukan pemeriksaan evaluasi laboratorium darah rutin dan kimia klinik. $\mathrm{Hb} 14.3 \mathrm{~g} / \mathrm{dL}$, Leukosit $10.100 / \mathrm{uL}$, granulosit $84.9 \%$, trombosit 26.000 / uL, CRP 1,0 mg/dL, prokalsitonin < 0,05 ng/ml, analisa gas darah tanpa oksigen dengan $\mathrm{pH} 7.46, \mathrm{pCO}_{2} 32 \mathrm{mmHg}$, pO2 $106 \mathrm{mmHg}, \mathrm{HCO}^{-}$22,8 mmol/l, BE -1,0 mml/, $\mathrm{SaO}_{2}$ $98 \%$. Konsultasi ke divisi bedah toraks dan kardiovaskuler dengan jawaban: Kami dapatkan pasien dengan fluido pneumotoraks dekstra rekuren post pleurodesis dan post torakoskopi dengan fistula bronkopleura paru dekstra. Pasien kami rencanakan torakotomi dekortikasi dan repair fistula. Jadwal kami acarakan.

Satu minggu MRS dilakukan pemeriksaan klinik pasien denagn keadaan umum cukup, kesadaran kompos mentis, dan pasien tidak sesak. Foto toraks evaluasi pre pembedahan terlihat paru terlihat sudah mulai mengembang bila dibandingkan dengan foto toraks sebelumnya. Pada lapangan paru kanan bawah masih terlihat gambaran paru sebelah kanan bawah masih tertutup oleh perselubungan homogen dengan gambaran efusi pleura, keesokan harinya keadaan umum pasien cukup baik, kesadaran kompos mentis dengan GCS 456. Pasien tidak merasa sesak dan tidak memakai bantuan oksigen tambahan. Analisa gas darah evaluasi tanpa oksigen: $\mathrm{pH} 7.44, \mathrm{pCO}_{2} 38 \mathrm{mmHg}$, pO2 $102 \mathrm{mmHg}, \mathrm{HCO} 3-25.8 \mathrm{mmol} / \mathrm{l}, \mathrm{BE} 1.6 \mathrm{mml} / \mathrm{l}, \mathrm{SaO}_{2}$ 98\%, AaDO2 87.

\section{Tahap operasi;}

Operasi dilakukan pada hari sembilan MRS yaitu operasi torakotomi dengan teknik torakotomi kanan klasik oleh divisi bedah toraks dan kardiovaskuler. Pasien dibaringkan dengan posisi left lateral decubitus. Sisi kiri berada di bawah, tangan kanan ekstensi. Pembiusan dilakukan dengan anestesi umum. Lapangan operasi didisinfeksi dengan savlon, povidon iodine $10 \%$, dan alkohol $70 \%$, kemudian lapangan oprasi dibatasi dengan doek kain steril 

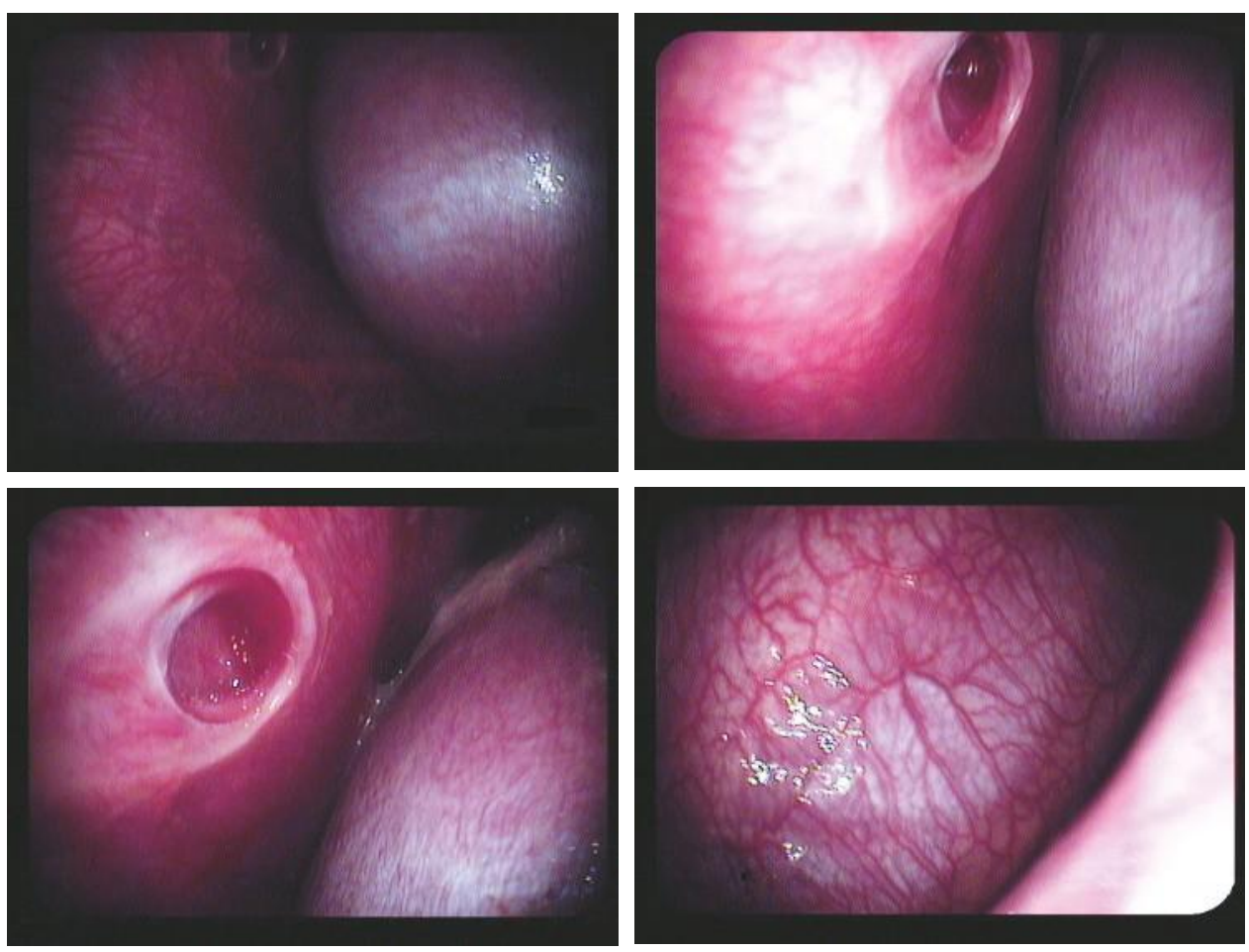

Gambar 2. Torakoskopi

pada bagian tepi dan doek transparan pada lokasi insisi. Dilakukan insisi, dinding dada dibuka lapis demi lapis melalui celah interkostal V. Tampak paru mengembang sebagian. Dilakukan eksplorasi lebih luas. Didapatkan fibrin-fibrin di permukaan paru dan terdapat beberapa tempat perlengketan ke dinding dada di bagian lobus superior dan lebih banyak pada lobus inferior. Didapaktan blep multiple sebanyak tiga buah dengan diameter $\pm 2 \mathrm{~cm}$ di lobus inferior dan blep-blep kecil dan sebagian bocor. Terdapat cairan pleura. (Lihat Gambar 3)

Parenkim paru lain tampak baik. Dilakukan dekortikasi, fibrin-fibrin dibebaskan. Dilakukan repair fistula pada blep dan salah satunya di segmentektomi. Dilakukan tes buble, kemudian dilakukan repair sampai tidak ditemukan buble lagi. Rawat perdarahan dan dilakukan pemasangan drain ukuran 28 Fr. Rongga dada ditutup dengan benang absorbable. Soft tissue ditutup lapis demi lapis. Tidak ditemukan komplikasi selama operasi dan pasca operasi.
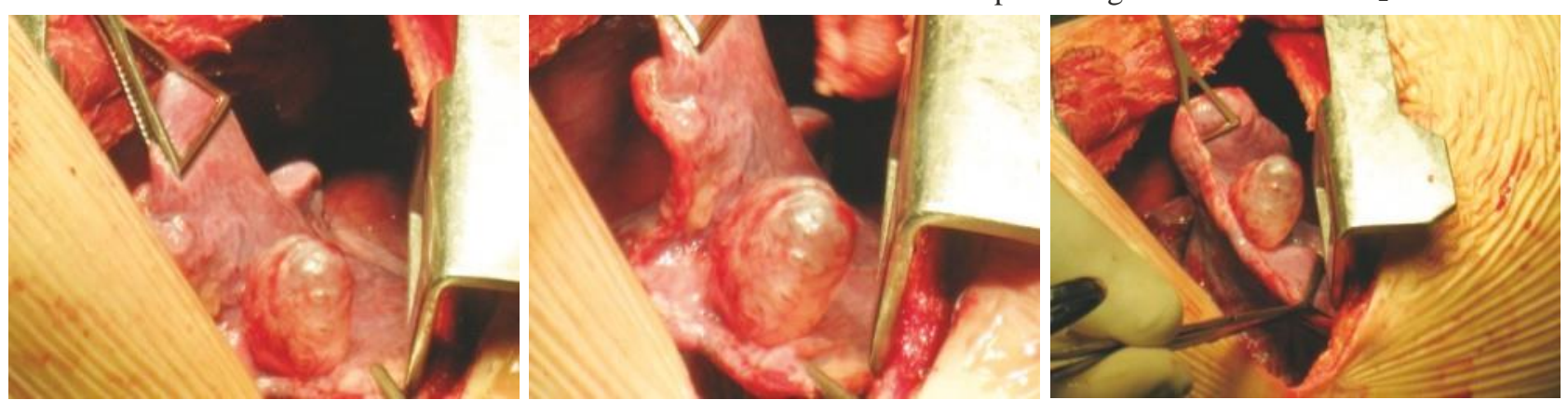

Terapi pasca pembedahan: IVFD PZ 1500 cc/24 jam, Cefazolin $3 \times 1 \mathrm{gr}$, Ketorolac $3 \times 30 \mathrm{mg}$, Ranitidine $2 \times$ 1

amp, Posisi slight head up, Sambung WSD + continuous suction -20 $\mathrm{cmH}_{2} \mathrm{O}$, Nebulisasi salbutamol/6 jam. Dilakukan monitoring: Cek darah rutin dan analisa gas darah, foto toraks evaluasi, produksi drain, buble ekspirasi. Hasil pemeriksaan hapusan cairan pleura: tidak ditemukan kuman batang tahan asam, tidak ditemukan kuman gram negatif atau gram positif. Laboratoriun darah pasca operasi: $\mathrm{Hb} 9.7 \mathrm{gr} / \mathrm{dL}$, leukosit $9.800 / \mathrm{mm}^{3}$, trombosit $283.000 / \mathrm{mm}^{3}$, glukosa $132 \mathrm{mg} / \mathrm{dl}$, SGOT 16 IU/L, SGPT $15 \mathrm{IU} / \mathrm{L}$, albumin $3.4 \mathrm{~g} / \mathrm{dL}$, BUN $5.2 \mathrm{mg} / \mathrm{dl}$, kreatinin $0.6 \mathrm{mg} / \mathrm{dl}$.Foto toraks pasca operasi: paru tampak mengembang dengan gambaran garis kolaps sangat minimal di bagian apeks paru kanan dan gambaran cairan di lapangan paru kanan bawah.

3. Tahap pasca operasi; Setelah operasi pembedahan, pasien dirawat di ruang palem II. Pasien tidak merasa sesak dan tidak memakai oksigen tambahan serta dilakukan pemasangan suction $-20 \mathrm{cmH}_{2} \mathrm{O}$. Pasien

Gambar 3. Blep multiple yang ditemukan selama operasi 
menjalani terapi pernapasan dan mobilisasi bertahap dari rehabilitasi medik. Pasien dilakukan klem pada chest tube dan dipertahankan selama 48 jam. Dua minggu MRS dilakukan foto toraks (Gambar 4) evaluasi pasca klem chest tube. Tidak ditemukan lagi gambaran kolaps paru efusi minimal.

Pada hari keenam belas MRS dilakukan pelepasan chest tube. Setelah keadaan cukup optimal dan tidak didapatkan komplikasi, keesokan harinya pasien dipulangkan dengan terapi cefixime $2 \times 200 \mathrm{mg}$, codein $3 \times 10 \mathrm{mg}$ dan dianjurkan oleh rehabilitasi medik untuk melakukan latihan napas dan latihan gerak di rumah.

\section{PEMBAHASAN}

Pneumotoraks adalah suatu kondisi di mana terdapat udara di dalam rongga pleura. ${ }^{1}$ Pneumotoraks dapat terjadi bila terdapat hubungan antara alveolus atau ruang udara intrapulmonar lainnya dengan rongga pleura. Udara akan mengalir masuk ke rongga pleura sampai tidak ada lagi perbedaan tekanan antara intrapulmonal dengan rongga pleura, atau bila penghubung ruang intrapulmonal dan rongga pleura tertutup. ${ }^{2}$ Berdasarkan penyebabnya, pneumotoraks dapat dibagi menjadi pneumotoraks artifisial, pneumotoraks traumatik, dan pneumotoraks spontan. Pneumotoraks spontan adalah pneumotoraks yang terjadi secara spontan tanpa didahului oleh kecelakaan atau trauma. Pneumotoraks spontan dibagi menjadi primer dan sekunder berdasarkan ada tidaknya penyakit penyebab yang mendasari. ${ }^{1,2,3}$

Insiden pneumotoraks diperkirakan sebanyak 8-12 kasus per 100.000 orang per tahun. Penumotoraks lebih sering terjadi pada penderita dewasa muda. Laki-laki lebih sering daripada perempuan. ${ }^{1}$ Insiden pneumotoraks spontan primer di Amerika Serikat adalah 7.4/100.000 per tahun pada laki-laki dan 1.2/100.000 per tahun pada perempuan. $^{2}$

Keluhan utama pneumotoraks spontan adalah sesak napas, bernapas terasa berat, nyeri dada, dan batuk. Sesak

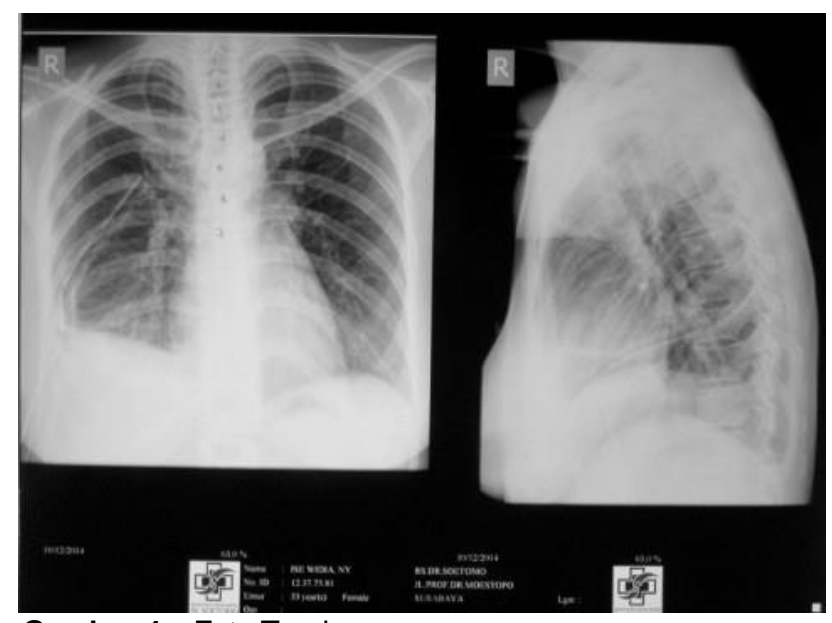

Gambar 4. Foto Toraks sering mendadak dan makin lama makin berat. Nyeri dada dapat dirasakan pada sisi yang sakit, rasa berat, tertekan, dan terasa lebih nyeri pada gerakan pernapasan. Diagnosis dapat ditegakkan dengan anamesis, pemeriksaan fisik, dan pemeriksaan penunjang. Meskipun dengan pemeriksaan foto toraks standar dapat terlihat adanya pneumotoraks, untuk melihat adanya blep subpleura, bulla, dan atau perubahan lokal dari paru emfisematus hanya dapat terlihat jelas pada pemeriksaan computed tomography (CT scan), inspeksi langsung pada pembedahan, pemeriksaan patologi dari spesimen, dan otopsi. Seringkali penyebab kebocoran ditemukan pada saat tindakan pembedahan. Gambaran patologik paru perokok dapat terlihat adanya proses inflamasi, perubahan vaskular, granulomatos, dan degeneratif.

Pneumotoraks spontan primer (PSP) terjadi akibat ruptur blep emfisematus subpleura, yang biasanya berlokasi di daerah apeks paru lobus superor atau inferior Blep dapat ditemukan pada $75 \%$ pasien pneumotoraks spontan primer yang menjalani torakoskopi. Patogenesis blep subpleura dan pencetus terjadinya ruptur alveoli masih belum diketahui secara pasti. ${ }^{2}$ Blep dapat timbul akibat abnormalitas kongenital, inflamasi bronkeoli, dan perubahan ventilasi kolateral. Terdapat hubungan yang kuat antara merokok dengan terjadinya (PSP). Pada penelitian yang dilakukan pada pasien PSP yang perokok dan mantan perokok, didapatkan angka kejadian PSP berhubungan dengan tingkat keparahan merokok. ${ }^{2,4}$ Pada laki-laki, risiko relatif terhadap pneumotoraks adalah tujuh kali lebih tinggi pada perokok ringan (1-2 batang rokok per hari), 21 kali lebih tinggi pada perokok sedang (13-22 batang rokok per hari), dan 102 kali lebh tinggi pada perokok berat (> 22 batang rokok per hari), bila dibandingkan dengan bukan perokok. Kelainan saluran napas kecil yang diinduksi oleh rokok dapat menyebabkan timbulnya blep subpleura. ${ }^{2}$

Konsep lama menyebutkan bahwa pada PSP terjadi akibat kebocoran udara tunggal (one single aisway) yang berasal dari satu blep yang pecah. Data terbaru menunjukkan hal yang berbeda dari konsep tersebut. Sebuah studi baru yang dilakukan pada pasien PSP dengan menggunakan fluoresen inhalasi, ditemukan aliran udara ke pleura berasal dari lebih dari satu kebocoran, sehingga menimbulkan "pleural porosity", di mana kebocoran udara berasal dari lubang multiple pada pleura viseralis. ${ }^{2}$

Di Inggris, mariyuana merupakan obat terlarang yang paling banyak digunakan penduduk usia 16-59 tahun dari tahun 2010 sampai 2011. Angka tersebut menunjukkan 1,1 juta penduduk Inggris menggunakan mariyuana pada tahun tersebut. Merokok mariyuana lebih banyak ditemukan usia kurang dari 35 tahun. Kesadaran publik tentang efek bahaya dari mariyuana terhadap paru masih sangat rendah. ${ }^{5}$ Pada perokok berat, mereka sering menggabungkan merokok dengan tembakau dan mariyuana. Hal ini sering menyulitkan untuk membedakan pengaruh buruk merokok akibat mariyuana dengan akibat tembakau. ${ }^{6}$

Terdapat perbedaan bahan aktif yang terdapat pada mariyuana dan tembakau. Hanya mariyuana yang 
mengandung tetrahydrocanabinol (THC) dan hanya tembakau yang mengandung nikotin. Pada sisi lain, mariyuana dan tembakau juga mengandung substansi yang sama dalam jumlah besar, seperti karbon monoksida, tar, dan karsinogen. Jumlah perokok mariyuana lebih sedikit dibandingkan dengan perokok tembakau. Saat merokok mariyuana, orang akan mengambil napas penuh ke dalam mulutnya sekitar dua pertiga lebih banyak dibandingkan dengan saat merokok tembakau. Volume inhalasi juga lebih besar saat merokok mariyuana. Mekanisme batuk pada saat sedang inspirasi diduga menjadi sebab timbulnya robekan alveokus dan menimbulkan blep. Bila terjadi robekan pada blep oleh sebab apapun, akan terjadi pneumotoraks. ${ }^{5,7,8}$

Merokok merupakan faktor risiko terjadinya pneumotoraks. Dari penelitian didapatkan bahwa risiko terjadinya pneumotoraks akibat merokok mariyuana dan tembakau sekaligus adalah lebih berisiko dibandingkan dengan hanya merokok tembakau saja. Merokok dengan keduanya akan memberikan efek sinergis yang dalam menimbulkan pneumotoraks. ${ }^{5,7,8}$

Pada paru pasien dengan PSP, hampir $81 \%$ ditemukan emphysematous-like effect (ELC). ELC yang ditemukan berupa blep atau bulla. Dari CT scan didapatkan ELC sering ditemukan bilateral dengan lokasi predominan di segmen apikal dari lobus superior dan inferior. ELC bilateral ditemukan sebanyak $79 \%$ sampai $93 \%$ pada pasien yang menjalani operasi sternotomi. Mekanisme pasti terbentuknya ELC masih dalam spekulasi. Mekanisme yang sangat mungkin adalah akibat terjadinya degradasi jaringan elastik paru. ${ }^{9}$

Kerusakan paru terjadi secara lambat dan progresif. Neutrofil, makrofag, dan sel inflamasi lainnya akan masuk ke paru oleh pengaruh asap rokok. Sel inflamasi dan sel epithelial akan menghasilkan protease yang akan mendegradasi komponen jaringan penunjang parenkim paru, termasuk elastin yang merupakan jaringan penunjang utama di paru. Hal tersebut akan mengakibatkan bronkiol dan alveoli kehilangan elastisitasnya. Beberapa peneliti mengemukakan bahwa terdapat perbedaan tekanan alveolar di bagian apeks paru dibandingkan dengan daerah basal paru. Pada daerah tersebut, alveoli yang telah kehilangan elastisitasnya tidak mampu lagi menahan tekanan tinggi. Tekanan yang tinggi tersebut akan dialirkan ke bronkiolus. Karena bronkiolus juga telah kehilangan elastisitasnya dan tidak cukup elastik lagi untuk menahan tekanan tersebut, alveoli akan ruptur. Pada daerah alveoli yang ruptur tersebut, udara akan masuk ke subpleura dan mengakibatkan terjadinya kumpulan udara di subpleura (blep). Pecahnya blep akan menimbulka aliran udara masuk ke rongga pleura dan timbul pneumotoraks. ${ }^{10}$

Pneumotoraks kurang dari $15 \%$ tidak membutuhkan intervensi. Pada observasi dilakukan pada pneumotorak yang lebih dari $15 \%$ dengan sesak napas ringan. Pada kondisi udara minimal daam rongga toraks, udara akan cepar direabsorbsi. Kecepatan reabsorbsi diperkirakan sebesar $1,22 \%$ paru per hari. Oleh karena itu, pasen penumotoraks primer dengan kebocoran udara minimal dapat melakukan rawat jalan. Pasien dengan pneumotoraks $20 \%$, absorbsi seluruh udara dalam rongga pleura secara spontan membutuhkan waktu 16 hari. Apabila pasien dirawat inap, pasen harus diberikan oksigen untuk dapat meningkatkan absorbsi udara dalam rongga pleura. ${ }^{2,3}$

Pilihan terapi utama pasien PSP dengan kolaps lebih dari $15 \%$ adalah aspirasi sederhana. Prosedur ini berhasil pada hampir $60 \%$ pasien PSP. Bila tindakan ini berhasil, maka pasien tidak peru dirawat inap dan terhindar dari nyeri akibat pemasangan selang torakostomi. Angka rekurensi sama antara aspirasi sederhana dan pemakaian selang torakostomi. ${ }^{2}$ Aspirasi sederhana membutuhkan latihan minimal, jarang membutuhkan rawat inap, dan dapat memprediksi jumlah sisa udara yang masih ada di paru dan ukuran kebocoran. Tindakan ini dilakukan dengan jarum yang relatif kecil (16 gauge) dengan yang dimasukkan kedalam celah interkostal dua anterior pada garis midklavikula. Three-way stopcock dan syringe $60 \mathrm{cc}$ disambungkan dengan kateter tadi. Udara dalam rongga pleura diaspirasi sampai habis. Bila udara masih terus dapat dengan mudah diaspirasi, hal tersebut menandakan bahwa terjadi kebocoran udara dalam jumlah besar. Paru seharusnya mengembang kembali setelah dilakukan aspirasi. Apabila beberapa menit kemudian udara kembali dapat diaspirasi dalam jumlah kecil, hal tersebut menandakan bahwa terjadi kebocoran udara yang kecil. Bila setelah batuk, udara tetap tidak dapat diaspirasi lagi, hal tersebut menandakan pneumotoraks tertutup, dan setelah dikonfirmasikan secara radiologis bahwa paru tetap mengembang, pasien dapat dipulangkan. Bila tindakan aspirasi tidak berhasil, dapat dipertimbangkan untuk melakukan torakoskopi atau pemasangan selang torakostomi. ${ }^{2,3}$

Tindakan ini direkomendasikan bila tindakan aspirasi sederhana tidak berhasil dan tidak ada torakoskopi di tempat pelayanan tersebut. pemakaian selang dengan ukuran kecil (8-16 French) lebih efektif dibandingkan dengan selang ukuran besar. Karena risiko terjadinya edema paru setelah reekspansi cepat paru, disarankan untuk menggunakan water-sealed drainagea (WSD) dan hindari melakukan suction dalam 24 jam pertama pemasangan selang tersebut.(muray) Bila paru telah mengalami reekspansi dan kebocoran udara tidak terjadi lagi dalam 24 jam, selang torakostomi dalat dilepaskan. Kebocoran udara dapat terlihat dengan adanya gelembung udara ke dalam WSD, bila tidak ditemukan gelembung udara pada pernapasan cukup, pasien diminta untuk batu. Bila gelembung udara tetap tidak ada, merupakan indikasi tidak adanya kebocoran udara. Bila paru tetap tidak mengalami reekspansi atau masih terjadi kebocoran udara ke dalam rongga pleura setelah 72 jam torakostomi, pertimbangkan untuk melakukan torakoskopi atau torakotomi. ${ }^{2}$

Pada pasien ini telah dilakukan pemasangan selang torakostomi dari rumah sakit yang merujuk atas indikasi ditemukannya pneumotoraks totalis. 
Karena banyak pasien PSP mengalami rekurensi, instilasi pleurodesis ke dalam rongga pleura dapat mengurangi angka rekurensi. Pemberian agen pleurodesis akan menurunkan angka rekurensi dari $40 \%$ menjadi $25 \%$. Agen pleurodesis yang paling banyak digunakan adalah talk dan doksisiklin. Dapat juga digunakan tetrasiklin. Bleomisin tidak direkomendasikan untuk digunakan. ${ }^{2}$

Video-assisted thoracoscopy surgery (VATS) merupakan prosedur yang dipilih apabila tindakan aspirasi sederhana mengalami kegagalan atau pasien mengalami pneumotoraks rekuren. Selama VATS, dapat dilakukan penghilangan blep penyebab pneumotoraks dan dilakukan pleurodesis. Pada blep dapat dilakukan endo-stapling. Bila bleb stapling tanpa dilakukan pleurodesis, angka rekurensi akan meningkat dan tindakan ini tidak dianjurkan. VATS merupakan manajemen efektif untuk PSP. Angka rekureni sekitar 5,4\%. Komplikasi VATS yang paling sering adalah terdapatnya kebocoran udara yang persisten (kurang dari $5 \%$ ). ${ }^{2,3}$

Bila tidak memiliiki fasilitas VATS, open thoracotomy merupakan pilihan alternatif yang dapat diambil. Sebaiknya dilakukan transaksilaris torakotomi untuk meminimialisasi trauma. Angka rekurensi PSP setelah open thoracotomy lebih rendah dari VATS, yaitu 1,1\% tetapi membutuhkan masa rawatan yang lebih lama dan morbiditas postoperative yang lebih tinggi. ${ }^{2}$

Pada pasien harus dilakukan manajemen postoperatif. Chest tube harus disambungkan dengan suction untuk dapat menimbulkan simpisis pleura. Chest tube dapat dilepas pada hari kedua apabila tidak terdapat kebocoran udara. Pasien dianjurkan untuk membatasi aktifitas yang dapat meningkatkan tekanan intratorakal selama empat minggu. ${ }^{11}$

\section{KESIMPULAN}

Telah dilaporkan seorang perempuan, 33 tahun, rujukan dari rumah sakit swasta dengan pneumotoraks dekstra totalis dan telah dilakukan pemasangan selang torakal dan dilakukan pleurodesis, tetapi paru kemudian kolaps kembali berdasarkan evaluasi foto toraks. Di RSUD Dr. Soetomo dilakuakan tindakan torakoskopi dan ditemukan fistula dengan ukuran besar. Pasien kemudian dikonsultasikan ke bagian bedah toraks dan kardiovaskuler untuk penutupan fistula. Selama operasi torakotomi didapatkan blep multiple sebanyak tiga buah dengan diameter $\pm 2 \mathrm{~cm}$ di lobus inferior dan blep-blep kecil dan sebagian bocor. Dilakukan dekortikasi, fibrin-fibrin dibebaskan. Dilakukan repair fistula pada blep dan salah satunya di segmentektomi. Keadaan pasien setelah operasi membaik dengan gambaran foto toraks tidak terdapat garis kolaps paru. Pasien dipulangkan dalam keadaan baik.

\section{DAFTAR PUSTAKA}

1. Wibisono, MJ, Winariani, Slamet $\mathrm{H}$. Buku ajar ilmu penyakit paru. Departemen Ilmu Penyakit Paru FK UNAIR - RSUD Dr. Soetomo. Surabaya. 2010. HIm: 180-197

2. Mason, RJ, Courtney B, Thomas RM, et al. Murray \& Nadel's textbook of respiratory medicine $5^{\text {th }}$ ed volume II. Saunders Elsevier. Phiadelphia. 2010. HIm: 1764-1770

3. Light RW, Gary L. Textbook of pleural disease. Hodder Arnold and Hachette UK company. London. 2008. HIm: 516-526

4. Tan C, Hatam, Tom T. Bullous disease of the lung and cannabis smoking: insufficient evidence for causative link. Journal of the royal society of medicine. London. 2006. HIm: 77-80

5. British Lung Foundation. The impact of cannabis on your lung. 2012

6. Tashkin DP, Calvarese BM, Simmons MS. Respiratory status of 74 habitual marituana smoker. Chest. 1980. HIm: 699-706

7. Goodyear K, Laws D and Turner J. 2004. Bilateral spontaneous pneumothorax in a cannabis smoker. In: J R Soc Med. , Sep, 97(9), 435-436 $p$

8. Feldman AL, Sullivan JT, Passero MA at al. 1993. Pneumothorax in polysubstance abusing marijuana and tobacco smokers: three cases. In: J Subst Abuse, 5, 183-186 p

9. Klingman RR, Vito AA, Tom RD. Cystic and bullous lung disease. Annual thoracic surgery. Los Angeles. 1991. HIm: 576.

10. Shields TW, Joseph LC, Reed CE. General Thoracic Surgery. William and Wilkins company. USA. 2012. HIm: 738-741.

11. Greenberg GA, Singhal S, Kaiser LR. Bullous lung disease: evaluation, selection, techniques, and outcome. Chest surgery Clin North Am. 2003. HIm: 631. 